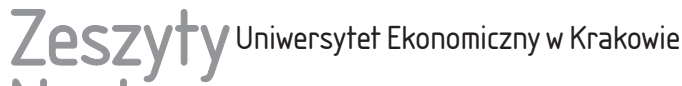 Naukowe
}

\section{Zastosowanie taksonomii do aktualizacji wartości zabezpieczenia hipotecznego nieruchomości mieszkaniowych w bankach na przykładzie Wrocławia}

\section{Streszczenie}

Regulacje KNF w zakresie kształtowania ryzyka kredytowego w portfelach banków i zarządzania nim obligują je do przeszacowywania wartości nieruchomości będących zabezpieczeniem kredytów hipotecznych. Korzystając z możliwości zastosowania na polskim rynku analizy statystycznej do określenia wartości nieruchomości, podejmuje się prace nad zastosowaniem innych metod określania wartości nieruchomości niż wskazane w Rozporządzeniu Rady Ministrów z dnia 21 września 2004 r. w sprawie wyceny nieruchomości i sporządzania operatu szacunkowego.

Magdalena Bywalec, Uniwersytet Ekonomiczny we Wrocławiu, Wydział Zarządzania, Informatyki i Finansów, Katedra Bankowości, ul. Komandorska 118/120, 53-345 Wrocław, e-mail: magdalena.bywalec@ue.wroc.pl

Anita Makowska, Uniwersytet Ekonomiczny we Wrocławiu, Wydział Zarządzania, Informatyki i Finansów, Katedra Inwestycji Finansowych i Zarządzania Ryzykiem, ul. Komandorska 118/120, 53-345 Wrocław, e-mail: anita.makowska@ue.wroc.pl 
Celem artykułu jest wskazanie możliwości aplikacyjnych oraz konsekwencji zastosowania metody taksonomicznej do aktualizacji wartości zabezpieczenia hipotecznego w bankach. W artykule porównano wyceny nieruchomości tradycyjną metodą porównywania parami (mpp) z wyceną metodą wzorca. Aktualizacja bankowego portfela nieruchomości mieszkaniowych dokonana na koniec 2016 r. metodą mpp to 50 wycen skorygowanych in minus i 47 in plus. Aktualizacja z wykorzystaniem metody wzorca wskazała 29 korekt in minus i 68 korekt in plus w wariancie I oraz 32 korekty in minus i 65 in plus w wariancie II. Zauważalna jest przewaga wzrostów wartości, co skutkowało większą zaktualizowaną wartością portfela, który w wariancie I osiągnął 33742 098,85 zł, a w wariancie II 33754 650,85 zł. W obu wariantach wartość portfela nieruchomości po zaktualizowaniu metodą wzorca wzrosła.

Słowa kluczowe: wycena nieruchomości, kredyty hipoteczne, metoda taksonomiczna, metoda porównywania parami, zabezpieczenie hipoteczne.

Klasyfikacja JEL: B41, E39, G21, R00, C00.

\section{Zarys problemu badawczego}

Obecnie obowiązujące w Polsce regulacje prawne dotyczące wyceny nieruchomości w sektorze bankowym są stosunkowo obszerne, ale też rozproszone w wielu ustawach, rozporządzeniach i rekomendacjach tworzących ramy prawne także dla procesu aktualizacji wartości zabezpieczenia hipotecznego.

Ponadto jako istotne z punktu widzenia aktualizacji wartości zabezpieczenia hipotecznego należy wskazać Rozporządzenie Parlamentu Europejskiego i Rady z dnia 26 marca 2013 r. w sprawie wymogów ostrożnościowych dla instytucji kredytowych i firm inwestycyjnych. Art. 208 tegoż rozporządzenia dopuszcza wykorzystanie metod statystycznych do monitorowania wartości nieruchomości i określania nieruchomości wymagających aktualizacji wartości.

$\mathrm{W}$ wymienionych regulacjach polskich, a także $\mathrm{w}$ regulacjach europejskich wskazuje się na konieczność przeprowadzania indywidualnej, dla każdego banku, wyceny portfela zabezpieczenia hipotecznego.

Regulacje KNF w zakresie kształtowania i zarządzania ryzykiem kredytowym w portfelach banków obligują te instytucje do dokonywania przeszacowania wartości nieruchomości będących zabezpieczeniem kredytów hipotecznych. Rekomendacja S II wskazuje, że: „Bank powinien monitorować w sposób ciągły zmiany zachodzące na rynku nieruchomości, a nie rzadziej niż raz w roku powinien dokonywać weryfikacji wartości nieruchomości stanowiących zabezpieczenie posiadanych przez bank ekspozycji kredytowych" (Rekomendacja S i S II... 2013).

Przeprowadzenie takiego procesu tradycyjnymi metodami wyceny, z wykorzystaniem ekspertów, czego efektem byłby operat szacunkowy, jest jednak skomplikowane i wymaga posiadania dostępu do dużej grupy rzeczoznawców majątkowych, co czyni cały ten proces czasochłonnym i kosztochłonnym. Wydaje 
się zatem zasadne stwierdzenie, że każdorazowe zlecenie wykonania operatów szacunkowych aktualizujących wartość portfela zabezpieczeń hipotecznych w banku byłoby nieefektywne kosztowo, jak również miałoby niewątpliwie istotny wpływ na kształtowanie się kosztów kredytów hipotecznych. W długim okresie tego typu zabieg mógłby mieć wpływ na dostępność kredytów na rynku i na kondycję polskiej gospodarki.

Stosowane, dopuszczalne w Polsce metody wyceny nieruchomości wymagają zbyt dużego zaangażowania kapitałowo-osobowego, przez co przeprowadzenie rzetelnego procesu aktualizacji wartości całego portfela zabezpieczenia hipotecznego każdego z banków, z wykorzystaniem dotychczasowych metod, staje się właściwie niemożliwe. Dlatego też korzystając z możliwości zastosowania na polskim rynku analizy statystycznej do określenia wartości nieruchomości, podejmuje się prace nad zastosowaniem innych, niż wskazane w Rozporządzeniu Rady Ministrów z dnia 21 września 2004 r. ..., metod określania wartości nieruchomości.

Niniejszy artykuł jest pierwszym, w którym autorki starają się wskazać najlepszą metodę przeszacowywania wartości nieruchomości na potrzeby portfeli hipotecznych banków. Podjęty w artykule problem badawczy koncentruje się na analizie zbieżności i rozbieżności w wycenie nieruchomości metodą porównywania parami i metodą taksonomiczną.

Celem artykułu jest ukazanie możliwości aplikacyjnych oraz konsekwencji zastosowania metody taksonomicznej w procesie aktualizacji wartości zabezpieczenia hipotecznego w bankach. Celem pośrednim stała się analiza zbioru danych o nieruchomościach znajdującego się w posiadaniu wydziałów ewidencji gruntów i budynków z punktu widzenia przydatności bazy danych do celów przeszacowania wartości nieruchomości.

Zaprezentowane $\mathrm{w}$ artykule badania przeprowadzono w odniesieniu do zbioru nieruchomości mieszkaniowych aglomeracji wrocławskiej. Przyjęty do analizy zbiór nieruchomości symuluje portfel nieruchomości stanowiących zabezpieczenie dla udzielonych przez bank kredytów hipotecznych. W prezentowanym artykule dokonano porównania wycen nieruchomości tradycyjną metodą porównania parami z efektami wyceny metodą taksonomiczną.

Wnioskowanie dotyczące różnic w wycenach i zmian wartości nieruchomości przeprowadzono z punktu widzenia banku. Oceny metody taksonomicznej dokonano, biorąc pod uwagę jej przydatność i możliwości aplikacyjne w procesie aktualizacji wartości portfeli hipotecznych banków. 


\section{Aktualizacja wartości nieruchomości na rynku finansowym - istota i znaczenie}

Aktualizacja wartości nieruchomości to proces polegający na ponownym szacowaniu wartości nieruchomości, które wcześniej były już wyceniane i znajdują się cały czas w portfelu danego podmiotu. Celem jest uaktualnienie wartości nieruchomości zazwyczaj na konkretnie wskazany dzień. Aktualizacja wartości nieruchomości może wiązać się zarówno ze wzrostem, jak i ze spadkiem tej wartości. Uzależniona jest ona nie tylko od przyjętej metody, ale przede wszystkim od warunków rynkowych, które od momentu pierwotnej wyceny mogą, choć nie muszą, istotnie się zmieniać.

Wartość nieruchomości przeszacowuje się, biorąc pod uwagę różne aspekty działania rynku finansowego. Trzy, które wydają się najistotniejsze, to: aspekt bankowy, podatkowy i „ochronny”, związany z kwestią funkcjonowania zabezpieczenia hipotecznego dla papierów wartościowych znajdujących się w obrocie. $\mathrm{W}$ niniejszym artykule poruszone zostaną jedynie kwestie związane $\mathrm{z}$ aspektem bankowym.

Z punktu widzenia banku aktualizacja wartości nieruchomości będących zabezpieczeniem wierzytelności bankowych to proces, który zgodnie z Rekomendacją S II przygotowaną przez KNF powinien być przeprowadzany raz w roku. Celem tego przeszacowania jest głównie uaktualnienie wartości zabezpieczenia hipotecznego dla określonego portfela wierzytelności hipotecznych. W tym kontekście aktualizacja wartości nieruchomości powinna być traktowana jako element procesu oceny ryzyka kredytowego. Zaktualizowana wartość nieruchomości wskazuje, czy wartość portfela nieruchomości stanowiących gwarancję spłaty kredytów wzrosła, spadła, czy też nie zmieniła się w stosunku do wartości pierwotnej zawartej w operacie szacunkowym, który dostarczany jest do banku w pierwszej fazie procesu kredytowego. Jest to szczególnie istotne w odniesieniu do długoterminowych, wysokokwotowych kredytów hipotecznych, zaciąganych średnio na okres ok. 20 lat. Nieruchomość jest dla nich zazwyczaj głównym zabezpieczeniem spłaty, a zatem jakiekolwiek zmiany jej wartości, szczególnie spadki, mogą mieć bardzo negatywne konsekwencje dla banków. Oznaczają one bowiem wzrost ryzyka kredytowego i konieczność zawiązania w banku większych rezerw. Biorąc pod uwagę obecną wielkość portfeli hipotecznych polskich banków, które zgodnie z danymi ZBP (Raport Amron-Sarfin 2017) za I kw. 2017 r. osiągnęły wartość ponad 2 mln umów w sektorze ${ }^{1}$, oraz tendencje wzrostowe w zakresie

\footnotetext{
${ }^{1}$ Raport ZBP podaje dokładnie 2,083 mln sztuk umów kredytowych w polskim sektorze bankowym w I kw. 2017 r.
} 
liczby udzielonych kredytów ${ }^{2}$ i wartości portfeli tych kredytów, konsekwencje spadku wartości ich zabezpieczenia mogą być bardzo kosztowne i w rezultacie mogą negatywnie wpłynąć na stabilność banku i bezpieczeństwo jego funkcjonowania.

Regularna aktualizacja wartości nieruchomości pozwoliłaby bankom na stałe monitorowanie wysokości zabezpieczenia, a w sytuacji zagrożenia na podjęcie odpowiednich kroków w celu przeciwdziałania negatywnym skutkom zmian wartości nieruchomości na rynku.

Zgodnie z obowiązującym prawem bank indywidualnie może określać swoją wewnętrzną procedurę oceny wartości zabezpieczeń oraz kryteria ustalania tej wartości (Rekomendacja S i S II... 2013, Rozporządzenie Parlamentu Europejskiego i Rady z dnia 26 września 2013 r. ...), a także monitorowania wartości nieruchomości stanowiących zabezpieczenie wierzytelności banku. Bank może w tym celu wykorzystać metody analizy statystycznej rynku. W związku z takim stanem rzeczy obecnie trwa proces wypracowywania i przyjmowania najlepszych rozwiązań, które pozwoliłyby bankom na regularne portfelowe przeszacowywanie wartości ich zabezpieczeń, a z drugiej strony nie generowałyby nadmiernych kosztów. W ten właśnie nurt wpisują się badania, których wyniki są prezentowane w artykule.

W tym miejscu należy także wspomnieć o odpowiednich bazach danych koniecznych do przeprowadzenia aktualizacji wartości nieruchomości. W kontekście wyceny nieruchomości na potrzeby zabezpieczenia wierzytelności bankowych można już mówić o pewnym postępie w zakresie tworzenia baz danych o nieruchomościach, istnieje bowiem i jest rozbudowywana baza Amron-Sarfin dotycząca rynku nieruchomości ${ }^{3}$.

Kilka lat temu podjęto problem konieczności budowy wspólnej bazy danych wydziałów ewidencji gruntów i budynków, sądów rejonowych w zakresie ksiąg wieczystych i urzędu skarbowego. Jednakże do dzisiaj właściwie brak integracji tych baz, co przy dużych portfelach nieruchomości gminnych rodzi konieczność zatrudnienia rzeczoznawców do wyceny nieruchomości, którzy scaliliby informacje o nieruchomości w celu aktualizacji zasobów gminnych w tym zakresie. Baza danych wydziałów ewidencji gruntów i budynków jest w naszym odczuciu

\footnotetext{
${ }^{2}$ Raport Amron-Sarfin (2017) podaje, że w I kw. 2017 r. zawarto 50238 nowych umów kredytowych, co oznacza wzrost w stosunku do IV kw. 2016 r. o 19,84\% w zakresie liczby umów. Obserwowalny wzrost wartości umów kredytowych kształtował się na poziomie 12,58\% i wyniósł w I kw. 2017 r. 11,01 mld zł.

${ }^{3}$ Baza Amron-Sarfin tworzona przez Związek Banków Polskich obejmuje dane o nieruchomościach pochodzące nie tylko z systemu bankowego, ale również od rzeczoznawców i pośredników działających na rynku nieruchomości.
} 
zbyt uboga, aby mogła sama w sobie stanowić podstawę aktualizacji wartości nieruchomości na potrzeby podatkowe.

Przeprowadzone analizy, zaprezentowane w dalszej części artykułu, pokazały, że różnice w przeszacowaniu wartości nieruchomości przez rzeczoznawców majątkowych i wartości otrzymanej na podstawie bazy danych wydziału ewidencji gruntów i budynków mogą być znaczące.

W dalszej części artykułu skupiono się zatem na dwóch kwestiach. Po pierwsze, zaprezentowano krótki przegląd propozycji różnych zespołów badawczych co do zastosowania taksonomii w wycenie nieruchomości; wskazano główne kierunki zastosowania metod taksonomicznych. Po drugie, zaprezentowano analizy własne i wyniki symulacji zastosowania taksonomii w aktualizacji wartości nieruchomości znajdujących się w portfelu banku.

\section{Taksonomia w wycenie nieruchomości}

Rozporządzenie Rady Ministrów z dnia 21 września 2004 r. w sprawie wyceny nieruchomości oraz sporządzania operatu szacunkowego wskazuje, w podejściu porównawczym, trzy metody wyceny dopuszczalne w polskich warunkach. Dwie z nich - metodę porównania parami (mpp) i korygowania ceny średniej, można uznać za szczegółowo opisany standard rynkowy. Trzecia metoda, tj. metoda analizy statystycznej rynku, nie została jednak szczegółowo scharakteryzowana i tym samym stanowi ciekawą alternatywę dla pozostałych dwóch metod. Jedyny wymóg zawarty w Rozporządzeniu, w odniesieniu do analizy statystycznej rynku, to konieczność skonstruowania zbioru nieruchomości reprezentatywnych oraz wykorzystania metod stosowanych do analiz statystycznych.

Przy takim podejściu ustawodawcy powstała możliwość rozpatrywania innych niż wskazane w ustawie metod statystycznych przy wycenie nieruchomości. Najczęściej rozpatrywana w tym zakresie jest analiza regresji (Hozer 2001, Kokot 2004, Lis 2008).

J. Hozer (2008) wymienił przyczyny niezadowalających rezultatów zastosowania do wyceny liniowych modeli ekonometrycznych:

- nie zawsze liniowe relacje między wartością nieruchomości a jej atrybutami,

- problemy z pomiarem zmiennych objaśniających, z których nie wszystkie poddają się pomiarowi; powoduje to nielogiczne oceny parametrów mimo dużej dobroci dopasowania modelu w postaci wysokiego współczynnika determinacji;

- współliniowość zmiennych objaśniających niepozwalająca na precyzyjne określenie wpływu poszczególnych zmiennych objaśniających na wartość nieruchomości;

- niewłaściwa postać analityczna modeli. 
Co jakiś czas pojawia się zatem propozycja wycen opartych na metodach taksonomicznych. Taksonomię wykorzystuje się najczęściej do określania podobieństwa nieruchomości wycenianych oraz przy konstrukcji taksonomicznej miary atrakcyjności nieruchomości. Głos w dyskusji na ten temat zabrała I. Foryś (2010), która wskazuje na przydatność metod taksonomicznych do wyboru nieruchomości podobnych w procesie szacowania wartości spółdzielczego prawa do lokalu mieszkalnego. Inne spostrzeżenia $\mathrm{z}$ analiz przeprowadzonych przez I. Foryś wskazują, że taksonomia jako metoda porządkowania liniowego pozwala na obiektywną ocenę podobieństwa nieruchomości porównywanych ze względu na możliwość uwzględniania wielu cech, w tym także cech niemierzalnych, a w efekcie dobór tych z nich, które zapewniają najmniejszy błąd szacowania. I. Foryś podkreśla, że taksonomia zyskuje w praktyce, gdy zbiór obiektów jest duży i duża jest liczba opisujących je cech, czyli w warunkach, które powinny być spełnione przy aktualizacji wartości nieruchomości w portfelach bankowych. Ponadto taksonomia pozwala ominąć subiektywną ocenę wpływu cech nieruchomości na jej szacowaną wartość.

M. Doszyń i S. Gnat (2015) wskazują na użyteczność taksonomii w indywidualnej wycenie nieruchomości. Prezentowane przez nich propozycje odnoszą się do wykorzystania taksonomii do skonstruowania miary atrakcyjności nieruchomości, przez którą autorzy rozumieją miarę taksonomiczną, jaką jest syntetyczny miernik rozwoju. W swoich badaniach M. Doszyń i S. Gnat wykorzystali taksonomiczną miarę atrakcyjności nieruchomości jako zmienną objaśniającą do modelowania jednostkowej ceny transakcyjnej nieruchomości. Zaproponowana przez nich procedura wyceny indywidualnej nieruchomości wydaje się mniej czasochłonna i bardziej odpowiednia ze względu na mniejszą liczbę arbitralnych rozstrzygnięć.

Tematykę stosowania taksonomii w procesie wyceny nieruchomości poruszają w swych opracowaniach także R. Pawlukowicz (2010) oraz A. Mazur i D. Witkowska (2006).

Niewielka liczba publikacji poświęconych zagadnieniom wykorzystania taksonomii w wycenie nieruchomości wskazuje, że temat ten ma nadal duży potencjał badawczy. W referowanych w dalszej części artykułu badaniach skupiono się zatem na wykorzystaniu taksonomii do wyceny portfela nieruchomości stanowiących zabezpieczenie wierzytelności hipotecznych banków. 


\section{Metodyka badania}

Badania prezentowane w niniejszym artykule przeprowadzono na próbie 97 losowo wybranych nieruchomości mieszkaniowych ${ }^{4}$, które zostały kupione/ sprzedane we Wrocławiu w 2011 r. Nieruchomości do próby losowano z bazy 10222 nieruchomości mieszkaniowych wykazanych w wydziale ewidencji gruntów i budynków jako te, którymi obrót nastąpił w 2011 r. Próba 97 nieruchomości reprezentowała $\mathrm{w}$ badaniu hipotetyczny portfel nieruchomości zabezpieczających kredyty udzielone przez Bank XYZ w 2011 r.

97 nieruchomości z hipotetycznego portfela bankowego zostało następnie wycenionych na $2011 \mathrm{r}$. z wykorzystaniem metody porównywania parami (mpp). Wycena dokonana została na podstawie transakcji nieruchomościami mieszkaniowymi z Wrocławia z lat 2010 i 2011. Ostateczna, sumaryczna wartość nieruchomości znajdujących się w analizowanym portfelu Banku XYZ w 2011 r., biorąc pod uwagę wyceny tych nieruchomości wykonane metodą mpp, kształtowała się na poziomie 31276760,13 zł.

Następnie przeprowadzono proces aktualizacji wartości nieruchomości z portfela Banku XYZ na 2016 r. Ponieważ głównym celem badania była analiza różnic $\mathrm{w}$ wycenie $1 \mathrm{~m}^{2}$ uzyskanej w wyniku aktualizacji wartości nieruchomości mieszkaniowych z portfela Banku XYZ metodą tradycyjną mpp z wynikiem aktualizacji uzyskanym przy zastosowaniu metody taksonomicznej, w dalszej części badań dokonano najpierw aktualizacji wartości 97 nieruchomości z $2011 \mathrm{r}$. metodą mpp. Do przeprowadzenia tej aktualizacji wykorzystano zbiór 4064 nieruchomości mieszkaniowych we Wrocławiu, którymi obrót miał miejsce w $2016 \mathrm{r}$. Na podstawie tego zbioru nieruchomości przeszacowano wartość $1 \mathrm{~m}^{2}$ każdej z 97 nieruchomości metodą mpp, dzięki czemu uzyskano także zaktualizowaną, sumaryczną wartość portfela nieruchomości Banku XYZ, która wyniosła $30080785,35 \mathrm{zł}$.

Po aktualizacji portfela nieruchomości Banku XYZ okazało się, że zaktualizowana na 2016 r. wartość tego portfela jest o 1195 974,78 zł niższa od wartości w 2011 r. Oznacza to spadek wartości portfela nieruchomości bankowych utworzonego w 2011 r. o 3,82\% w 2016 r. Taka sytuacja niewątpliwie powinna wiązać się w Banku XYZ z przeszacowaniem zobowiązań kredytowych i ponowną analizą ryzyka kredytowego dla portfela kredytów hipotecznych zabezpieczonych na analizowanym portfelu 97 nieruchomości.

\footnotetext{
${ }^{4}$ Próbę ograniczono do 97 nieruchomości, gdyż w prezentowanych badaniach była konieczność wyceny każdej z tych nieruchomości metodą porównywania parami, co jest procesem czasochłonnym i autorki nie były w stanie samodzielnie przeprowadzić wyceny większej liczby nieruchomości. Niemniej z punktu widzenia wartości globalnej tego portfela nieruchomości można uznać, że jest on na tyle duży, że może pełnić funkcję grupy badawczej w przeprowadzonych analizach.
} 
W kolejnym etapie wykorzystano metodę taksonomiczną do wyznaczania wartości $1 \mathrm{~m}^{2}$ każdej z 97 analizowanych nieruchomości mieszkaniowych.

Po pierwsze, wykorzystując dostępną bazę danych, dokonano wyboru zmiennych do analizy. Wybrano cztery zmienne:

$a$ - prawo do gruntu,

$b$ - piętro,

$c$ - liczba izb,

$d$ - powierzchnia.

Po drugie, przekształcono zmienne zgodnie ze schematem podanym w tabeli 1 .

Tabela 1. Schemat przekształcenia analizowanych zmiennych

\begin{tabular}{|l|l|c|}
\hline \multicolumn{1}{|c|}{ Zmienna } & \multicolumn{1}{|c|}{ Cechy zmiennej } & $\begin{array}{c}\text { Przekształcenie zmiennej } \\
\text { na potrzeby analizy }\end{array}$ \\
\hline $\begin{array}{l}\text { Rodzaj nabywanego prawa } \\
\text { do gruntu }\end{array}$ & $\begin{array}{l}\text { Współużytkowanie } \\
\text { lub użytkowanie wieczyste }\end{array}$ & 0 \\
\cline { 2 - 3 } & Współwłasność lub własność & 1 \\
\hline \multirow{5}{*}{ Piętro } & Parter & 0 \\
\cline { 2 - 3 } & 1 lub 2 piętro & 2 \\
\cline { 2 - 3 } & 3 lub 4 piętro & 1 \\
\cline { 2 - 3 } & 5 lub wyższe piętro & 3 \\
\hline \multirow{5}{*}{ Liczba izb } & 1 lub 2 izby & 2 \\
\cline { 2 - 3 } & 3 lub 4 izby & 2 \\
\cline { 2 - 3 } & 5 lub więcej izb & 3 \\
\hline Powierzchnia & Do $45 \mathrm{~m}^{2}$ & 1 \\
\cline { 2 - 3 } & $45-55 \mathrm{~m}^{2}$ & 0 \\
\cline { 2 - 3 } & $55-80 \mathrm{~m}^{2}$ & 2 \\
\cline { 2 - 3 } & Powyżej $80 \mathrm{~m}^{2}$ & 2 \\
\hline
\end{tabular}

Źródło: opracowanie własne.

Wskazanego przekształcenia dokonano w kontekście aktualizacji wartości nieruchomości na potrzeby zabezpieczenia wierzytelności bankowych. Przy takim ujęciu problemu zasadne wydaje się, by najwyżej ocenić ten typ nieruchomości, które w danym roku były najczęściej sprzedawane. Takie nieruchomości z dużym prawdopodobieństwem będą mogły być najszybciej sprzedane w przypadku skwantyfikowania się ryzyka kredytowego w portfelu banku. Możliwość szybkiego „upłynnienia” zabezpieczenia to bowiem nie tylko możliwość szybkiego odzyskania zaangażowanego w kredyt czy pożyczkę kapitału, ale także mniejszy koszt ponoszony przez bank $\mathrm{w}$ związku z przeprowadzeniem procesu windykacji z zabezpieczenia, jakim jest nieruchomość. W odniesieniu do nieruchomości 
najczęściej sprzedawanych zasadne wydaje się wskazanie, że ze względu na mniejsze koszty ponoszone w tym przypadku przez bank (koszty przygotowania i przeprowadzenia przetargu czy licytacji) oraz zazwyczaj duże zainteresowanie klientów takimi nieruchomościami, możliwe jest uzyskanie najkorzystniejszej ceny za metr kwadratowy ${ }^{5}$.

Przy ustalaniu powyższych przekształceń kierowano się:

a) analizą danych rynkowych dotyczących transakcji nieruchomościami mieszkaniowymi we Wrocławiu,

b) analizami prowadzonymi przez ZBP, których wyniki publikowane są w kwartalnych raportach Amron-Sarfin (Raport Amron-Sarfin 2016), oraz wynikami z raportu NBP pt. Informacja o cenach mieszkań i sytuacji na rynku nieruchomości mieszkaniowych i komercyjnych w Polsce w IV kw. 2016 roku (Łaszek $\mathrm{i}$ in. 2017),

c) opiniami ekspertów w zakresie wyceny nieruchomości.

Po trzecie, ustalono parametry wzorca, który charakteryzował się maksymalnymi wartościami zmiennych. Oznacza to, że wzorzec stanowiła nieruchomość mieszkaniowa:

- będąca we współwłasności lub własności,

- umiejscowiona na 1 lub 2 piętrze,

- posiadająca 1 lub 2 izby,

- o powierzchni $45-55 \mathrm{~m}^{2}$.

Zmienne mierzone były na skali porządkowej.

Po czwarte, po określeniu wzorca obliczono odległość GDM (generalized distance measure), zaproponowaną przez M. Walesiaka (Walesiak 2002, 2004, Walesiak i Gatnar 2004). Odległość liczono dla każdej z 97 analizowanych nieruchomości z portfela Banku XYZ między daną nieruchomością a nieruchomością wzorcową.

GDM wykorzystuje zarówno współczynnik korelacji liniowej Pearsona, jak i współczynnik korelacji tau Kendalla. Ogólny wzór przedstawia się następująco:

$$
d_{i i^{\prime \prime}}=\frac{1}{2}-\frac{\sum_{j=1}^{m} w_{j} a_{i i^{\prime} j} b_{i{ }^{\prime} j}+\sum_{j=1}^{m} \sum_{i^{\prime \prime}}^{n} w_{j} a_{i i^{\prime \prime} j} b_{i i^{\prime \prime} j}}{2\left[\sum_{j=1}^{m} \sum_{i^{\prime \prime}=1}^{n} w_{j} a_{i i^{\prime \prime} j}^{2} \cdot \sum_{j=1}^{m} \sum_{i^{\prime \prime}=1}^{n} w_{j} b_{i^{\prime \prime} i^{\prime \prime} j}^{2}\right]^{\frac{1}{2}},}
$$

\footnotetext{
${ }^{5}$ Założenie to może wydawać się daleko posunięte, ale zdaniem autorek w kontekście przeprowadzonych badań i zachowań rynkowych klientów jest zasadne.
} 
gdzie:

$w_{j}$ - waga $j$-tej zmiennej,

$i, i^{\prime}, i^{\prime \prime}=1, \ldots, n-$ numer obiektu,

$j=1, \ldots, m-$ numer zmiennej.

W powyższej formule stosuje się następujące podstawienie dla zmiennych $a$ i $b$ mierzonych na skali porządkowej:

$$
a_{i k j}\left(b_{i^{\prime} l j}\right)=\left\{\begin{array}{lll}
1 & \text { dla } x_{i j}>x_{k j} & \left(x_{i^{\prime} j}>x_{l j}\right) \\
0 & \text { dla } x_{i j}=x_{k j} & \left(x_{i^{\prime} j}=x_{l j}\right), \\
-1 & \text { dla } x_{i j}<x_{k j} & \left(x_{i^{\prime} j}<x_{l j}\right)
\end{array}\right.
$$

gdzie:

$$
\begin{aligned}
& k=i^{\prime}, i^{\prime \prime}, \\
& l=i, i^{\prime \prime}
\end{aligned}
$$

oraz

- dla porównywanych obiektów $i, i^{\prime \prime}$ :

$$
a_{i i^{\prime} j} b_{i^{\prime} i j}=\left\{\begin{array}{lll}
1 & \text { dla } & x_{i j}=x_{i^{\prime} j} \\
-1 & \text { dla } & x_{i j} \neq x_{i^{\prime} j}
\end{array},\right.
$$

- dla pozostałych obiektów $\left(i^{\prime \prime}=1, \ldots, n, i^{\prime \prime} \neq i, i^{\prime}\right)$ :

$$
a_{i i^{\prime \prime} j} b_{i^{\prime} i^{\prime \prime} j}=\left\{\begin{array}{lll}
1 & \text { dla } & x_{i j}=x_{i^{\prime} j} \wedge\left(x_{i j}, x_{i^{\prime} j}=x_{i^{\prime \prime} j} \vee x_{i j} x_{i^{\prime} j} \neq x_{i^{\prime \prime} j}\right. \\
-1 & \text { dla } & x_{i j} \neq x_{i^{\prime} j} \wedge\left(x_{i j}, x_{i^{\prime} j}=x_{i^{\prime \prime} j} \vee x_{i j} \neq x_{i^{\prime \prime} j}, x_{i^{\prime} j}=x_{i^{\prime \prime} j} \vee x_{i j}=x_{i^{\prime \prime} j}, x_{i^{\prime} j} \neq x_{i^{\prime \prime} j}\right),
\end{array}\right.
$$

gdzie w formułach (2), (3) i (4) $x_{i j}\left(x_{i^{\prime} j}, x_{i^{\prime \prime} j}\right)-i$-ta (i'-ta, $i^{\prime \prime}$-ta) obserwowanej j-tej zmiennej.

Odległość GDM wyznaczono dla dwóch wariantów.

Wariant I - dla wszystkich cech przyjęto równe wagi, tzn. 25\%, a następnie policzono odległość GDM zgodnie z wzorem (1), wykorzystując język programowania R (pakiet clusterSim).

Wariant II - dla poszczególnych cech przyjęto różne wagi:

- forma własności - waga 0,1 ,

- piętro - waga 0,2,

- liczba izb - waga 0,4 ,

- powierzchnia - waga 0,3. 
Wagi określono na podstawie analiz rynkowych oraz opinii ekspertów ${ }^{6}$. W opinii autorek proces określania wag do obliczenia odległości $G D M$ powinien być przedmiotem bardziej szczegółowej analizy

Po piąte, wyznaczono dodatkowo miarę bliskości $\left(s_{i, i^{\prime \prime}}\right)$ według poniższego wzoru (Gatnar 1998, Panek 2009):

$$
s_{i, i^{\prime \prime}}=1-d_{i, i^{\prime \prime}-G D M},
$$

przy założeniu że: $d_{i, i^{\prime \prime}, G D M} \neq 1$.

Trzeba zaznaczyć, że gdy miara odległości $\left(d_{i, i^{\prime \prime} G D M}\right)$ rośnie, zmniejsza się stopień podobieństwa analizowanych obiektów, w tym przypadku nieruchomości. Wzrost miary bliskości oznacza natomiast wzrost stopnia podobieństwa nieruchomości, a zatem również wzrost podobieństwa w odniesieniu do wartości jednostkowej nieruchomości wzorcowej.

Mając wyznaczone miary odległości $G D M$, miarę bliskości oraz maksymalne możliwe do uzyskania w 2016 r. wartości $1 \mathrm{~m}^{2}$ dla poszczególnych obrębów Wrocławia, można było wyznaczyć zaktualizowaną wartość 97 nieruchomości z 2011 r. Aktualizacja wartości $1 \mathrm{~m}^{2}$ tych nieruchomości nastąpiła przez wyznaczenie dla każdej z nich iloczynu maksymalnej wartości $1 \mathrm{~m}^{2} \mathrm{w}$ danym obrębie i miary bliskości każdej z 97 analizowanych nieruchomości. Uzyskane wyniki poddane zostały następnie analizie.

Jednocześnie warto zauważyć, że w przypadku gdy miara odległości wyniesie 1 (dwie skrajnie różne nieruchomości), wartość nieruchomości wyznaczona za pomocą tej metody będzie równa zero. Konieczne jest zatem założenie, że do takiej sytuacji nie dojdzie, gdyż w podejściu porównawczym nacisk położony jest na wykorzystanie w analizie tzw. nieruchomości podobnych. Niemniej jednak założenie, że $d_{i, i^{\prime \prime}, G D M} \neq 1$ wydaje się konieczne.

Rozwiązaniem problemu skrajnie różnych nieruchomości mogących wystąpić w niniejszym badaniu mogłaby być interpolacja z wykorzystaniem miary podobieństwa, co niewątpliwie może stanowić ciekawe rozwinięcie badań zaprezentowanych w tej pracy.

\footnotetext{
${ }^{6}$ Ekspertami w badaniach byli wybrani rzeczoznawcy majątkowi zajmujący się od kilkunastu lat wyceną nieruchomości na terenie Dolnego Śląska.

${ }^{7}$ Szczegółowe analizy dotyczące wag nie są przedmiotem niniejszej pracy, będą tematem innego, opracowywanego przez autorki artykułu.
} 


\section{Wyniki przeprowadzonych badań i analiz}

Aktualizacji portfela 97 nieruchomości mieszkaniowych dokonano na koniec 2016 r. Wynik aktualizacji dokonanej standardową metodą mpp to 50 nieruchomości skorygowanych in minus i 47 in plus. Maksymalne i minimalne korekty in plus i in minus $\mathrm{w}$ poszczególnych obrębach prezentuje tabela 2.

Tabela 2. Wynik aktualizacji na 2016 r. metodą porównywania parami (korekty w poszczególnych obrębach)

\begin{tabular}{|c|c|c|c|c|c|}
\hline \multirow{2}{*}{ Obręb } & \multirow{2}{*}{$\begin{array}{c}\text { Liczba } \\
\text { transakcji } \\
\text { analizowanych }\end{array}$} & \multicolumn{2}{|c|}{ Korekty in minus } & \multicolumn{2}{|c|}{ Korekty in plus } \\
\hline & & $\max$ & $\min$ & $\max$ & $\min$ \\
\hline Brochów & 1 & - & 440,41 & - & - \\
\hline Dąbie & 1 & - & - & - & 393,9 \\
\hline Gaj & 2 & - & - & 155,75 & 1295,38 \\
\hline Gądów Mały & 2 & - & 1059,04 & - & 75,79 \\
\hline Grabiszyn & 15 & 63,31 & 1361,99 & 41,08 & 970,6 \\
\hline Jagodno & 1 & - & - & - & 242,14 \\
\hline Kleczków & 1 & - & - & - & 362,91 \\
\hline Kozanów & 1 & - & 1611,13 & - & - \\
\hline Krzyki & 1 & - & 1494,98 & - & - \\
\hline Maślice & 1 & - & 115,25 & - & - \\
\hline Muchobór Wielki & 1 & - & 475,02 & - & - \\
\hline Osobowice & 3 & 748,67 & 1632,52 & - & 430,6 \\
\hline Partynice & 6 & 430,62 & 1748,26 & 100,26 & 228,24 \\
\hline Plac Grunwaldzki & 19 & 115,62 & 2033,28 & 30,56 & 1982,51 \\
\hline Południe & 19 & 164,94 & 2140,1 & 93,12 & 1888,96 \\
\hline Poświętne & 4 & 50,15 & 869,39 & - & 472,77 \\
\hline Różanka & 1 & - & - & - & 624,96 \\
\hline Sępolno & 1 & - & 1086,12 & - & - \\
\hline Stabłowice & 2 & 265,18 & 290,57 & - & - \\
\hline Stare Miasto & 12 & 233,84 & 2611,27 & 259,55 & 1239,09 \\
\hline Tarnogaj & 1 & - & - & - & 387,7 \\
\hline Wojszyce & 1 & - & 69,26 & - & - \\
\hline Zakrzów & 1 & - & 462,55 & - & - \\
\hline
\end{tabular}

Źródło: opracowanie własne.

Na podstawie danych zaprezentowanych w tabeli 2 można stwierdzić, że najwyższe korekty in plus wartości $1 \mathrm{~m}^{2}$ dla analizowanych 97 nieruchomości 
mieszkaniowych odnotowano w obrębach: Plac Grunwaldzki, Południe, Gaj i Stare Miasto. Najwyższe korekty in minus dotyczyły obrębów Stare Miasto, Południe i Plac Grunwaldzki.

Analizując liczbę wszystkich 4064 transakcji nieruchomościami z 2016 r., które stanowiły podstawę aktualizacji metodą mpp, można łatwo zauważyć, że największe zmiany in plus i in minus pojawiają się w odniesieniu do tych obrębów Wrocławia, w których miało miejsce najwięcej transakcji kupna/sprzedaży nieruchomości mieszkaniowych. Tabela 3 prezentuje liczbę transakcji kupna/sprzedaży nieruchomości w przyjętej do badań bazie z 2016 r.

Tabela 3. Liczba transakcji kupna/sprzedaży nieruchomości w bazie z $2016 \mathrm{r}$. w wybranych obrębach Wrocławia

\begin{tabular}{|l|c|l|c|}
\hline \multicolumn{1}{|c|}{ Obręb } & Liczba transakcji & \multicolumn{1}{c|}{ Obręb } & Liczba transakcji \\
\hline Brochów & 58 & Partynice & 171 \\
\hline Dąbie & 20 & Plac Grunwaldzki & 469 \\
\hline Gaj & 181 & Południe & 488 \\
\hline Gądów Mały & 53 & Poświętne & 25 \\
\hline Grabiszyn & 271 & Różanka & 89 \\
\hline Jagodno & 33 & Sępolno & 63 \\
\hline Kleczków & 53 & Sołtysowice & 50 \\
\hline Kozanów & 25 & Stabłowice & 137 \\
\hline Krzyki & 106 & Stare Miasto & 444 \\
\hline Maślice & 33 & Tarnogaj & 49 \\
\hline Muchobór Wielki & 125 & Wojszyce & 92 \\
\hline Osobowice & 14 & Zakrzów & 54 \\
\hline
\end{tabular}

Źródło: opracowanie własne.

Aktualizacja wartości $1 \mathrm{~m}^{2} 97$ nieruchomości z portfela Banku XYZ z 2011 r. z wykorzystaniem metody taksonomicznej wzorca przeprowadzona na 2016 r. pozwoliła na uzyskanie 29 korekt in minus i 68 korekt in plus $\mathrm{w}$ wariancie I analizy i 32 korekty in minus oraz 65 in plus w wariancie II. Tabele 4 i 5 prezentują rozpiętość korekt aktualizacji metodą wzorca.

Zauważalna jest zdecydowana przewaga wzrostów wartości $1 \mathrm{~m}^{2}$, co przekłada się na większą wartość portfela przeszacowywanych nieruchomości, który w wariancie I osiągnął wartość 33742 098,85 zł, a w wariancie II 33754 650,85 zł. Zarówno w wariancie I, jak i II wartość portfela nieruchomości po zaktualizowaniu ich metodą wzorca uległa wzrostowi. Z punktu widzenia banku sytuacja jest w tym przypadku korzystniejsza niż przy aktualizacji metodą mpp. 
Tabela 4. Wyniki aktualizacji wartości nieruchomości na 2016 r. metodą wzorca w wariancie I (wskazania maksimum i minimum korekt in plus i in minus w analizowanych obrębach)

\begin{tabular}{|c|c|c|c|c|}
\hline \multirow{3}{*}{ Obręb } & \multicolumn{4}{|c|}{ Wariant I } \\
\hline & \multicolumn{2}{|c|}{ korekty in minus } & \multicolumn{2}{|c|}{ korekty in plus } \\
\hline & $\min$ & $\max$ & $\min$ & $\max$ \\
\hline Brochów & - & - & 154,51 & - \\
\hline Dąbie & - & 2006,18 & - & - \\
\hline Gaj & - & - & 1094,62 & 2774,23 \\
\hline Gądów Mały & 1398,06 & 2220,28 & - & - \\
\hline Grabiszyn & 131,64 & 3498,34 & 108,41 & 2553,61 \\
\hline Jagodno & 1042,08 & - & - & - \\
\hline Kleczków & - & - & - & 2334,56 \\
\hline Kozanów & 1614,97 & - & - & - \\
\hline Krzyki & 1484,03 & - & - & - \\
\hline Maślice & - & - & 586,88 & - \\
\hline Muchobór Wielki & 974,81 & - & - & - \\
\hline Osobowice & 480,68 & - & 143,4 & 1904,09 \\
\hline Partynice & 981,56 & 1007,74 & 1294,1 & 1273,8 \\
\hline Plac Grunwaldzki & 480,57 & 898,91 & 223,77 & 5187,68 \\
\hline Południe & 1156,4 & 2553,86 & 423,57 & 4704,1 \\
\hline Poświętne & - & - & 328,06 & 1936,1 \\
\hline Różanka & - & - & - & 2313,28 \\
\hline Sępolno & - & 1176,42 & - & - \\
\hline Stabłowice & - & 1249,1 & - & 1723,76 \\
\hline Stare Miasto & 726,61 & 2421,09 & 248,75 & 3395,12 \\
\hline Tarnogaj & 527,13 & - & - & - \\
\hline Wojszyce & - & - & 571,7 & - \\
\hline Zakrzów & - & 1549,5 & - & - \\
\hline
\end{tabular}

Źródło: opracowanie własne.

Analizując tabelę 4, można zauważyć, że największe korekty in plus odnotowane zostały w wariancie I w obrębach: Plac Grunwaldzki, Południe, Stare Miasto i Gaj, podobnie jak to miało miejsce w przypadku zastosowania metody mpp. W wariancie II analizy (zob. tabela 5) największe korekty in plus odnotowano w obrębach: Plac Grunwaldzki, Południe, Stare Miasto i Grabiszyn. $\mathrm{Z}$ wyjątkiem obrębu Grabiszyn wyniki dotyczące korekt in plus w analizowanym portfelu nieruchomości są podobne jak w wariancie I i w metodzie mpp. Zmiany w wariancie II wynikają z dużym prawdopodobieństwem z położenia większego 
nacisku na liczbę izb i powierzchnię, a mniejszego na formę własności. Wśród analizowanych nieruchomości w obrębie Grabiszyn było zdecydowanie więcej nieruchomości jedno- lub dwupokojowych, które były traktowane jako te bliższe wzorcowi i przyznano im najwyższą miarę (3). W obrębie Stare Miasto przeważały nieruchomości trzy- lub czteropokojowe, które miały miarę (2), gdyż nie odpowiadały nieruchomościom wzorcowym. Takie wyniki utwierdzają w przekonaniu, że dobór odpowiednich wag do metody wzorca powinien być przedmiotem dalszych badań.

Tabela 5. Wyniki aktualizacji wartości nieruchomości na 2016 r. metodą wzorca w wariancie II (wskazania maksimum i minimum korekt in plus i in minus w analizowanych obrębach)

\begin{tabular}{|c|c|c|c|c|}
\hline \multirow{3}{*}{ Obręb } & \multicolumn{4}{|c|}{ Wariant II } \\
\hline & \multicolumn{2}{|c|}{ korekty in minus } & \multicolumn{2}{|c|}{ korekty in plus } \\
\hline & $\min$ & $\max$ & $\min$ & $\max$ \\
\hline Brochów & - & 684,14 & - & - \\
\hline Dąbie & - & 1546,45 & - & - \\
\hline Gaj & - & - & 869,14 & 2160,13 \\
\hline Gądów Mały & 1286,08 & 2639,06 & - & - \\
\hline Grabiszyn & 492,66 & 3352,84 & 504,46 & 2452,03 \\
\hline Jagodno & - & 1744,34 & - & - \\
\hline Kleczków & - & - & - & 2253,11 \\
\hline Kozanów & - & 2049,44 & - & - \\
\hline Krzyki & - & 1727,05 & - & - \\
\hline Maślice & - & - & - & 508,29 \\
\hline Muchobór Wielki & - & 1871,9 & - & - \\
\hline Osobowice & - & 480,68 & - & 1904,09 \\
\hline Partynice & 1264,84 & 2033,12 & 41 & 2201,27 \\
\hline Plac Grunwaldzki & 350,1 & 753,61 & 835,32 & 5947,08 \\
\hline Południe & 191,94 & 3326,24 & 807,25 & 4788,13 \\
\hline Poświętne & - & - & 386,58 & 1452,95 \\
\hline Różanka & - & - & - & 1819,13 \\
\hline Sępolno & - & 1104,28 & - & - \\
\hline Stabłowice & - & 1298,72 & - & 1474,26 \\
\hline Stare Miasto & 152,18 & 1730,77 & 277,62 & 3503,87 \\
\hline Tarnogaj & - & - & - & 196,33 \\
\hline Wojszyce & - & - & - & 490,62 \\
\hline Zakrzów & - & 1963,07 & - & - \\
\hline
\end{tabular}

Źródło: opracowanie własne. 
Można przyjąć, że w metodzie taksonomicznej poprawnie zostały odzwierciedlone zachowania rynkowe klientów. Różnice w stosunku do metody mpp występują niewątpliwie w wysokości dokonywanych korekt, które w przypadku metody wzorca są ponad dwukrotnie wyższe od tych wskazanych w metodzie mpp. Tabela 6 prezentuje różnice korekt in plus i in minus między metodą mpp i metodą wzorca w wariancie I i II.

$\mathrm{Z}$ danych tabeli 4 wynika, że największe korekty in minus uzyskano, aktualizując portfel 97 nieruchomości metodą wzorca w wariancie I, w odniesieniu do takich obrębów, jak: Grabiszyn, Południe, Stare Miasto i Gądów Mały. $\mathrm{W}$ wariancie II (zob. tabela 5) obrębami o największych korektach in minus były: Grabiszyn, Południe i Gądów Mały. W przypadku Starego Miasta w wariancie II dzięki przyjęciu innych wag uzyskano mniejsze różnice między metodą wzorca a mpp w aktualizacji wartości $1 \mathrm{~m}^{2}$ nieruchomości.

W tej sytuacji, podobnie jak w metodzie porównywania parami (mpp), pojawiają się obręby Południe i Stare Miasto jako jedne z tych, które charakteryzują się największymi korektami in minus. Dodatkowo w przypadku metody wzorca w wariancie I jako obręby z największymi korektami wartości $1 \mathrm{~m}^{2}$ in minus odnotowano Grabiszyn i Gądów Mały.

Tabela 6. Różnice maksymalnych korekt wartości $1 \mathrm{~m}^{2}$ nieruchomości z 2011 r. przeszacowanych na $2016 \mathrm{r}$. w wybranych obrębach Wrocławia

\begin{tabular}{|l|c|c|c|c|c|}
\hline \multirow{2}{*}{ Obręb } & \multicolumn{5}{c|}{ Korekty in plus } \\
\cline { 2 - 6 } & mpp & wzorzec I & $\begin{array}{c}\text { wzorzec I } \\
\text { jako \% mpp }\end{array}$ & wzorzec II & $\begin{array}{c}\text { wzorzec II } \\
\text { jako \% mpp }\end{array}$ \\
\hline Gaj & 1295,38 & 2774,23 & 214,16 & 2160,13 & 166,76 \\
\hline Plac Grunwaldzki & 1982,51 & 5187,68 & 261,67 & 5947,08 & 299,98 \\
\hline Południe & 1888,96 & 4704,1 & 249,03 & 4789,13 & 253,53 \\
\hline Stare Miasto & 1239,09 & 3395,12 & 274,00 & 3503,87 & 282,78 \\
\hline Grabiszyn & 970,6 & 2553,61 & 263,10 & 2452,03 & 252,63 \\
\hline Gądów Mały & 65,79 & - & - & - & - \\
\hline \multirow{7}{*}{ Obręb } & mpp & wzorzec I & $\begin{array}{c}\text { Wzorzec I } \\
\text { jako \% mpp }\end{array}$ & wzorzec II & $\begin{array}{c}\text { wzorzec II } \\
\text { jako \% mpp }\end{array}$ \\
\cline { 2 - 7 } & - & - & - & - & - \\
\hline Gaj & 2033,28 & 898,91 & 44,21 & 753,61 & 37,06 \\
\hline Plac Grunwaldzki & 2140,1 & 2553,8 & 119,33 & 3326,24 & 155,42 \\
\hline Południe & 2611,27 & 2421,09 & 92,72 & 1730,77 & 66,28 \\
\hline Stare Miasto & 1361,99 & 3498,34 & 256,86 & 3352,84 & 246,17 \\
\hline Grabiszyn & 1059,04 & 2220,28 & 209,65 & 2639,06 & 249,19 \\
\hline Gądów Mały & & \multicolumn{5}{|c|}{} \\
\hline
\end{tabular}

Źródło: opracowanie własne. 
W odniesieniu do obrębu Grabiszyn trzeba zauważyć, że w przypadku zastosowania metody mpp nie miał on co prawda najwyższych wartości korekt in minus, ale wartości te były wysokie (był to 7 najwyższy wynik spośród 23 obrębów występujących w przeszacowywanym portfelu nieruchomości).

Ciekawym zagadnieniem okazały się w trakcie analiz różnice w jednostkowej aktualizacji wartości $1 \mathrm{~m}^{2}$ nieruchomości z portfela Banku XYZ pomiędzy metodą mpp a metodą wzorca.

Tabela 7. Maksymalne i minimalne różnice w aktualizacji wartości $1 \mathrm{~m}^{2}$ nieruchomości między metodą wzorca a mpp w 2016 r. w poszczególnych obrębach

\begin{tabular}{|c|c|c|c|c|}
\hline \multirow[b]{2}{*}{ Obręb } & \multicolumn{2}{|c|}{ Wariant I } & \multicolumn{2}{|c|}{ Wariant II } \\
\hline & $\begin{array}{c}\max \\
\text { (wartość wyższa } \\
\text { od tej w meto- } \\
\text { dzie wzorca) }\end{array}$ & $\min$ & $\max$ & $\min$ \\
\hline Brochów & 594,92 & - & - & $-243,73$ \\
\hline Dąbie & 2400,08 & - & - & $-1940,35$ \\
\hline Gaj & 2618,48 & $-200,76$ & 2004,38 & $-426,23$ \\
\hline Gądów Mały & - & $-2296,06$ & & $-2714,84$ \\
\hline Grabiszyn & 2066,26 & $-2552,85$ & 2208,63 & $-2407,34$ \\
\hline Jagodno & - & $-1284,22$ & - & $-1986,48$ \\
\hline Kleczków & 1971,65 & - & 1890,2 & - \\
\hline Kozanów & - & $-3,84$ & - & $-438,31$ \\
\hline Krzyki & 10,95 & - & - & $-232,07$ \\
\hline Maślice & 702,13 & - & 623,54 & - \\
\hline Muchobór Wielki & 499,75 & - & - & $-1396,88$ \\
\hline Osobowice & 1473,5 & - & 1473,5 & - \\
\hline Partynice & 3259,59 & $-248,38$ & 3363,53 & $-1299,94$ \\
\hline Plac Grunwaldzki & 3969,52 & $-404,19$ & 4728,93 & $-1279,46$ \\
\hline Południe & 4827,12 & $-578,72$ & 4709,12 & $-1548,3$ \\
\hline Poświętne & 1542,73 & - & 1460,57 & - \\
\hline Różanka & 1688,32 & - & 1194,17 & - \\
\hline Sępolno & - & $-90,3$ & - & $-18,16$ \\
\hline Stabłowice & 2014,33 & $-983,92$ & 1764,84 & -1033 \\
\hline Stare Miasto & 2513,44 & $-374,17$ & 2458,32 & $-517,18$ \\
\hline Tarnogaj & - & $-914,84$ & - & $-191,38$ \\
\hline Wojszyce & 640,96 & - & 559,88 & - \\
\hline Zakrzów & - & $-1086,94$ & - & $-1500,52$ \\
\hline
\end{tabular}

Źródło: opracowanie własne. 
Analiza wyników różnic w przeszacowaniu wartości $1 \mathrm{~m}^{2}$ nieruchomości między metodą wzorca w wariancie I a metodą mpp wskazała na 70 przypadków, w których metoda wzorca sugeruje wyższą wartość $1 \mathrm{~m}^{2}$ nieruchomości niż metoda mpp; 27 przypadków było odwrotnych. W wariancie II w 69 przypadkach wartość $1 \mathrm{~m}^{2}$ nieruchomości wskazana w metodzie wzorca była wyższa niż w metodzie mpp, w 28 przypadkach była niższa.

Jak można wywnioskować z analizy tabeli 7, najbardziej zbliżone w obu metodach wartości przeszacowania $1 \mathrm{~m}^{2}$ nieruchomości otrzymano dla obrębów Kozanów i Krzyki w wariancie I oraz obrębu Sępolno w wariancie II. Podobne niewielkie różnice $\mathrm{w}$ wycenie $1 \mathrm{~m}^{2}$ nieruchomości między metodą wzorca a mpp odnotowano w przypadku obrębów Brochów i Maślice.

Jako ostatnia prezentowana jest $\mathrm{w}$ artykule analiza zmian zaktualizowanej wartości $1 \mathrm{~m}^{2}$ nieruchomości metodą wzorca (tabela 9) na tle wartości minimalnych i maksymalnych $1 \mathrm{~m}^{2}$ nieruchomości, którymi obrót nastąpił w 2016 r. (tabela 8).

Tabela 8. Wartości maksymalne i minimalne $1 \mathrm{~m}^{2}$ nieruchomości, którymi obrót nastąpił w 2016 r., w wybranych obrębach Wrocławia

\begin{tabular}{|l|c|c|}
\hline \multirow{2}{*}{ Obręb } & \multicolumn{2}{|c|}{ Wartość } \\
\cline { 2 - 3 } & min & max \\
\hline Brochów & 3798,54 & 8717,95 \\
\hline Dąbie & 5146,68 & 10005,16 \\
\hline Gaj & 3360,49 & 9586,65 \\
\hline Gądów Mały & 3523,28 & 7057,55 \\
\hline Grabiszyn & 3385,3 & 9145,82 \\
\hline Jagodno & 3724,14 & 6915,63 \\
\hline Kleczków & 3467,19 & 7476,64 \\
\hline Kozanów & 3888,89 & 6796,12 \\
\hline Krzyki & 4110,32 & 10332,87 \\
\hline Maślice & 3455,5 & 7214,14 \\
\hline Muchobór Wielki & 3487,97 & 7825,6 \\
\hline Osobowice & 3390,41 & 7406,07 \\
\hline Partynice & 3525,01 & 10931,17 \\
\hline Plac Grunwaldzki & 3369,45 & 10918,73 \\
\hline Południe & 3466,67 & 10831,67 \\
\hline Poświętne & 4596,75 & 7542,35 \\
\hline Różanka & 3363,39 & 7714,07 \\
\hline Sępolno & 3960,11 & 7581,57 \\
\hline Stabłowice & 3485,48 & 8174,83 \\
\hline
\end{tabular}


cd. tabeli 8

\begin{tabular}{|l|c|c|}
\hline \multirow{2}{*}{ Obręb } & \multicolumn{2}{|c|}{ Wartość } \\
\cline { 2 - 3 } & $\min$ & $\max$ \\
\hline Stare Miasto & 3376,02 & 11428,57 \\
\hline Tarnogaj & 3815,98 & 7682,38 \\
\hline Wojszyce & 3722,08 & 7443,58 \\
\hline Zakrzów & 3583,33 & 6185,57 \\
\hline
\end{tabular}

Źródło: opracowanie własne.

Tabela 9. Zaktualizowane metodą wzorca wartości maksymalne i minimalne $1 \mathrm{~m}^{2}$ dla nieruchomości znajdujących się w portfelu Banku XYZ w poszczególnych obrębach

\begin{tabular}{|l|c|c|c|c|}
\hline \multirow{2}{*}{ Obręb } & \multicolumn{2}{c|}{ Wariant I } & \multicolumn{2}{c|}{ Wariant II } \\
\cline { 2 - 5 } & $\min$ & $\max$ & $\min$ & $\max$ \\
\hline Brochów & - & 4700,82 & - & 3862,17 \\
\hline Dąbie & - & 5352,91 & - & 5812,64 \\
\hline Gaj & 5491,94 & 8562,97 & 5266,46 & 7948,87 \\
\hline Gądów Mały & 3643,71 & 4362,31 & 3224,93 & 4474,28 \\
\hline Grabiszyn & 3565,17 & 8169,22 & 3710,68 & 4755,58 \\
\hline Jagodno & - & 4866,71 & - & 4164,45 \\
\hline Kleczków & - & 6990,59 & - & 6909,15 \\
\hline Kozanów & - & 3686,94 & - & 3252,48 \\
\hline Krzyki & - & 5919,42 & - & 5676,4 \\
\hline Maślice & - & 6745,16 & - & 6666,57 \\
\hline Muchobór Wielki & - & 4789,8 & - & 3892,71 \\
\hline Osobowice & - & 7406,06 & - & 7406,07 \\
\hline Partynice & 5894,22 & 8425,51 & 4842,66 & 8529,52 \\
\hline Plac Grunwaldzki & 3915,19 & 9752 & 2937,82 & 10452,85 \\
\hline Południe & 3883,98 & 10127,54 & 2914,39 & 10369,5 \\
\hline Poświętne & 6407,01 & 7052,04 & 6253,82 & 6969,88 \\
\hline Różanka & - & 6890,35 & - & 6396,2 \\
\hline Sępolno & - & 5843,71 & - & 5915,85 \\
\hline Stabłowice & 4050,89 & 6690,18 & 4001,28 & 6440,69 \\
\hline Stare Miasto & 5786,78 & 8808,89 & 6187,35 & 9301,89 \\
\hline Tarnogaj & - & 4997,57 & - & 5711,03 \\
\hline Wojszyce & - & 6958,75 & - & 6877,68 \\
\hline Zakrzów & - & 3770,12 & - & 3356,55 \\
\hline
\end{tabular}

Źródło: opracowanie własne. 
Porównując zaktualizowane wartości $1 \mathrm{~m}^{2}$ nieruchomości z tabeli $9 \mathrm{z}$ wartościami $1 \mathrm{~m}^{2}$ nieruchomości z tabeli 8 , można zauważyć, że mimo rozbieżności $\mathrm{w}$ tych wartościach wyceny z zastosowaniem metody wzorca, w wariancie zarówno I, jak i II, mieszczą się w widełkach wycen obserwowanych w poszczególnych obrębach Wrocławia w 2016 r.

W metodzie wzorca większość maksymalnych wartości $1 \mathrm{~m}^{2}$ nieruchomości dla nieruchomości zaktualizowanych znajduje się w górnej granicy wartości wyznaczonych z wykorzystaniem bazy nieruchomości z 2016 r. W przypadku Osobowic można było zaobserwować, że maksymalna wartość $1 \mathrm{~m}^{2}$ uzyskana w metodzie wzorca niemal pokrywa się z górną granicą wyznaczoną z wykorzystaniem bazy z $2016 \mathrm{r}$.

\section{Wnioski}

Proces aktualizacji wartości nieruchomości w portfelach hipotecznych banków wydaje się istotny nie tylko z punktu widzenia samego banku, ale także z punktu widzenia klienta, który powinien być zainteresowany śledzeniem wartości swojego zabezpieczenia hipotecznego, szczególnie gdy problem ten rozpatruje się w kontekście długoterminowych kredytów hipotecznych.

Przeprowadzone badania i analizy pokazały, że argument wysokich kosztów procesu przeszacowania wartości nieruchomości w portfelach banków, najczęściej podnoszony przez przedstawicieli banków w dyskusjach nad problemem aktualizacji wartości zabezpieczenia hipotecznego, można podważyć. Jest bowiem możliwe wypracowanie w ramach dopuszczalnej metody analizy statystycznej rynku procedury aktualizowania wartości nieruchomości znajdujących się w portfelach banków, która byłaby tak dopasowana do danych, którymi dysponuje bank, aby otrzymane wyceny nie odbiegały znacząco od rzeczywistej sytuacji na rynku.

W opinii autorek prezentowana metoda taksonomiczna wykorzystująca do wyceny wzorzec jest jednym z możliwych rozwiązań w tym zakresie. Możliwości aplikacyjne tej metody są w naszym przekonaniu bardzo duże. Metoda nie wymaga od banków zatrudniania specjalistów do przeszacowywania wartości nieruchomości. Wymaga tworzenia jedynie rzetelnej wewnętrznej bazy danych, która powinna być wsparta danymi zewnętrznymi, dotyczącymi np. zainteresowania daną dzielnicą w konkretnym mieście. Wszelkie pozostałe dane na temat nieruchomości niezbędne w metodzie wzorca bank może uzyskać w procesie kredytowym (np. z operatu szacunkowego).

Niewątpliwie dużym wsparciem zarówno dla banków, jak i dla innych instytucji finansowych byłaby rzetelna i duża baza danych o nieruchomościach, która w opinii autorek powinna znajdować się w wydziale ewidencji gruntów i budynków. 
Głównym problemem wykorzystania metody taksonomicznej wzorca w procesie aktualizacji wartości nieruchomości oprócz ubogich baz danych jest kwestia wzorca. Wydaje się, że jest to najsłabszy punkt tej metody. Biorąc jednak pod uwagę fakt, że ZBP w ramach działalności Amron, a także NBP ze swoją grupą analityków rynku nieruchomości stale poszerzają prezentowany zakres raportów, problem wzorca w wycenie może już wkrótce nie stanowić wielkiej przeszkody.

Podsumowując, autorki pragną podkreślić, że prezentowany artykuł to tylko część badań nad problemem wyceny i aktualizacji wartości nieruchomości na potrzeby polskiego rynku finansowego.

\section{Literatura}

Doszyń M., Gnat S. (2015), Propozycje procedury taksonomiczno-ekonometrycznej w indywidualnej wycenie nieruchomości, „Prace Naukowe Uniwersytetu Ekonomicznego we Wrocławiu", nr 385.

Foryś I. (2010), Wykorzystanie metod taksonomicznych do wyboru obiektów podobnych w procesie wyceny lokali mieszkaniowych, „Studia i Materiały Towarzystwa Naukowego Nieruchomości", vol. 18, nr 1.

Gatnar E. (1998), Symboliczne metody klasyfikacji danych, Wydawnictwo Naukowe PWN, Warszawa.

Hozer J. (2001), Regresja wieloraka a wycena nieruchomości, „,Rzeczoznawca Majątkowy", $\mathrm{nr} 2$.

Hozer J. (2008), Wycena nieruchomości, Wydawnictwo Uniwersytetu Szczecińskiego, Szczecin.

Kokot S. (2004), Model wielu regresji pojedynczych w wycenie nieruchomości, „Studia i Materiały Towarzystwa Naukowego Nieruchomości”, vol. 12, nr 1.

Lis Ch. (2008), Wykorzystanie metod ilościowych w procesie powszechnej taksacji nieruchomości w Polsce (w:) Metody matematyczne, ekonometryczne i informatyczne w finansach i ubezpieczeniach, red. P. Chrzan, Wydawnictwo Akademii Ekonomicznej we Wrocławiu, Wrocław.

Łaszek J., Augustyniak H., Olszewski K., Waszczuk J., Widlak M. (2017), Informacja o cenach mieszkań $i$ sytuacji na rynku nieruchomości mieszkaniowych $i$ komercyjnych w Polsce w IV kw 2016 roku, NBP, Departament Stabilności Finansowej, Warszawa, marzec.

Mazur A., Witkowska D. (2006), Zastosowanie wybranych mierników taksonomicznych do oceny nieruchomości, ,Zeszyty Naukowe SGGW w Warszawie”, Ekonomika i Organizacja Gospodarki Żywnościowej, nr 60.

Panek T. (2009), Statystyczne metody wielowymiarowej analizy porównawczej, SGH, Warszawa.

Pawlukowicz R. (2010), Wykorzystanie metodyki porzadkowania liniowego do określania wartości rynkowej nieruchomości, „Prace Naukowe Uniwersytetu Ekonomicznego we Wrocławiu", nr 107. 
Walesiak M. (2002), Propozycja uogólnionej miary odległości w statystycznej analizie wielowymiarowej (w:) Statystyka regionalna w stużbie samorzadu lokalnego i biznesu, red. J. Paradysz, Internetowa Oficyna Wydawnicza, Centrum Statystyki Regionalnej, Poznań.

Walesiak M. (2004), Problemy decyzyjne w procesie klasyfikacji zbioru obiektów, „Prace Naukowe Akademii Ekonomicznej we Wrocławiu", nr 1010, Ekonometria 13.

Walesiak M., Gatnar E.(2004), Metody statystycznej analizy wielowymiarowej w badaniach marketingowych, Wydawnictwo Akademii Ekonomicznej we Wrocławiu, Wrocław.

Raport Amron-Sarfin (2016), 4/2016, nr 30, ZBP, Warszawa, luty.

Raport Amron-Sarfin (2017), 1/2017, nr 31, ZBP, Warszawa, 30 maja.

Rekomendacja S i S II dotycząca dobrych praktyk w zakresie zarządzania ekspozycjami kredytowymi zabezpieczonymi hipotecznie, z dnia 18 czerwca 2013 r. (2013), www. knf.gov.pl/dla_rynku/regulacje_i_praktyka/rekomendacje_i_wytyczne (data dostępu: 1.07.2017).

Rozporządzenie Parlamentu Europejskiego i Rady z dnia 26 marca 2013 r. w sprawie wymogów ostrożnościowych dla instytucji kredytowych i firm inwestycyjnych, www.knf.gov.pl/dla_rynku/regulacje_i_praktyka (data dostępu: 1.07.2017).

Rozporządzenie Rady Ministrów z dnia 21 września 2004 r. w sprawie wyceny nieruchomości i sporządzania operatu szacunkowego, Dz.U. nr 207, poz. 2109.

\section{The Use of Taxonomy to Update the Value of Bank Mortgage Collateral for Residential Real Estate - the Example of Wroclaw}

(Abstract)

The Polish Financial Supervision Authority’s regulations on credit risk management in bank portfolios require banks to update the value of real estate that provides collateral for mortgages. Using statistical analysis to determine the value of real estate on the Polish market, scientists and market practitioners are working on other methods of determining the value of real estate, as specified in the Regulation of the Council of Ministers of 21 September 2004 on the Real Estate Valuation and Appraisal Report.

The paper explains the uses and consequences of taxonomy to update the value of mortgage collateral in banks. It presents a comparison of a traditional real estate valuation method, paired comparison, with the effects of the valuation of the taxonomic method pattern. As a result of updating the value of residential property portfolios held by banks, done at the end of 2016, there were 50 valuations corrected in minus and 47 in plus. Updating the value of the real estate portfolio using based on taxonomic analysis indicated 29 corrections in minus and 68 corrections in plus in variant I and 32 in minus and 65 in plus in variant II. There was a noticeable increase in value, which results in a higher value of the portfolio, which in variant I reached PLN 33742098.85 in variant II PLN 33754 650.85. In both variants, the value of the real estate portfolio increased after the pattern update.

Keywords: property valuation, mortgages, taxonomic method, pair comparison method, mortgage security. 